\title{
The fate of seeds in the soil: a review of the influence of overland flow on seed removal and its consequences for the vegetation of arid and semiarid patchy ecosystems
}

\author{
E. Bochet \\ Centro de Investigaciones sobre Desertificación - CIDE (CSIC, UV, GV), Carretera de Moncada a Náquera \\ $\mathrm{km}$ 4.5, 46113 Moncada, Valencia, Spain \\ Correspondence to: E. Bochet (esther.bochet@uv.es)
}

Received: 14 August 2014 - Published in SOIL Discuss.: 16 October 2014

Revised: - - Accepted: 16 December 2014 - Published: 26 January 2015

\begin{abstract}
Since seeds are the principle means by which plants move across the landscape, the final fate of seeds plays a fundamental role in the assemblage, functioning and dynamics of plant communities. Once seeds land on the soil surface after being dispersed from the parent plant, they can be moved horizontally by surface runoff. In arid and semiarid patchy ecosystems, where seeds are scattered into a very heterogeneous environment and intense rainfalls occur, the transport of seeds by runoff to new sites may be an opportunity for seeds to reach more favourable sites for seed germination and seedling survival. Although seed transport by runoff may be of vital importance for the recruitment of plants in these ecosystems, it has received little attention in the scientific literature, especially among soil scientists. The main goals of this review paper are (1) to offer an updated conceptual model of seed fate with a focus on seed destiny in and on the soil; (2) to review studies on seed fate in overland flow and the ecological implications seed transport by runoff has for the origin, spatial patterning and maintenance of patches in arid and semiarid patchy ecosystems; and finally (3) to point out directions for future research.

This review shows that seed fate in overland flow may result either in the export of seeds from the system (seed loss) or in the spatial redistribution of seeds within the system through short-distance seed movements (seed displacement). Seed transport by runoff depends on rainfall, slope and soil characteristics. Susceptibility of seed removal varies highly between species and is mainly related to seed traits, including seed size, seed shape, presence of appendages, and ability of a seed to secrete mucilage. Although initially considered as a risk of seed loss, seed removal by runoff has recently been described as an ecological driver that shapes plant composition from the first phases of the plant life by favouring species with seeds able to resist erosion and by selecting for plant traits that prevent seed loss. Moreover, the interaction of seed transport by overland flow with the high seed trapping capacity of vegetated patches results in a "patch-to-patch" transport of seeds that plays a relevant role in vegetation establishment and patterning in arid and semiarid patchy ecosystems.

Overall, this review shows how the knowledge about seed fate in overland flow can be used to explain a number of important characteristics of whole plant communities. It also underlines important gaps in knowledge that should be filled in. Future lines of research are proposed in order to broaden our understanding of the origin, maintenance and dynamics of patchiness in arid and semiarid ecosystems and to improve restoration success of intensively eroded ecosystems. Among the most exciting challenges, empirical studies are needed to understand the relevance of short-distance seed displacements in the origin and maintenance of patchiness, addressing the feedbacks between structure and function and abiotic and biotic components, in order to validate existing models about the dynamics of arid and semiarid ecosystems and help to predict future changes under the scenarios of climate change.
\end{abstract}




\section{Introduction}

The term "seed fate" has been used to describe what happens to seeds from the moment they are produced by mother plants until they become seedlings. In the 1970s and 1980s, seed dispersal was described as a simple and direct process of seed movement from the mother plant to the final microsite where the seed germinates or dies. Seed dispersal was accomplished by different biotic or abiotic agents (wind, animals, gravity) and its outcome was considered stochastic. The possibility of further seed dispersal after seeds reached their first landing surface was not taken into account (Vander Wall et al., 2002; Forget and Wenny, 2002). The lack of empirical studies on the ultimate stages of dispersal, due to the difficulty of measuring seed dispersal (Bullock et al., 2006), led to incomplete information about the pathways seeds might follow until they germinate (Vander Wall et al., 2002). However, in the early 1990s, the development of a variety of new techniques that permitted researchers to follow seeds in space and time (metal detectors, fluorescent dyes, genetic tools) provided evidence that seed dispersal was a far more dynamic and complex process than was previously portrayed (Forget and Milleron, 1991; Chambers and Mac Mahon, 1994; Böhning-Gaese et al., 1999). It became evident that seed fate involved multiple steps and agents and its outcome was nonhazardous. Thus, after the initial movement of seeds from the mother plant to the first landing site ("primary" dispersal), a second dispersal stage started to be considered consisting of any significant subsequent vertical or horizontal seed movement from this original site ("secondary" dispersal; Chambers and Mac Mahon, 1994; Böhning-Gaese et al., 1999). A variety of biotic and abiotic agents, including overland flow, are responsible for the secondary dispersal of seeds to new sites of the landscape.

Since successful regeneration by a plant depends upon its seeds being dispersed to safe sites where seeds can germinate and seedlings can establish (Harper, 1977; Schupp, 1995), secondary dispersal gives seeds new opportunities to reach favourable sites. This second chance may be of vital importance for seeds in hostile environments with extreme environmental regimes where most points of the landscape are unsuitable for seed germination, seed survival and seedling establishment. This is the case in arid and semiarid environments, also called "drylands", which cover over $40 \%$ of the Earth's surface (Reynolds et al., 2007). These water-limited landscapes frequently show a clear spatial pattern of vegetated patches interspersed within a bare soil matrix (Aguiar and Sala, 1999) which gives rise to a mosaic-like structure of sources and sinks of resources, the bare and vegetated patches, respectively, with very different soil properties and variable interconnection (e.g. Schlesinger et al., 1990; Ludwig and Tongway, 1995; Bochet et al., 1999, 2000; Puigdefábregas, 2005). Vegetated patches have often been com-

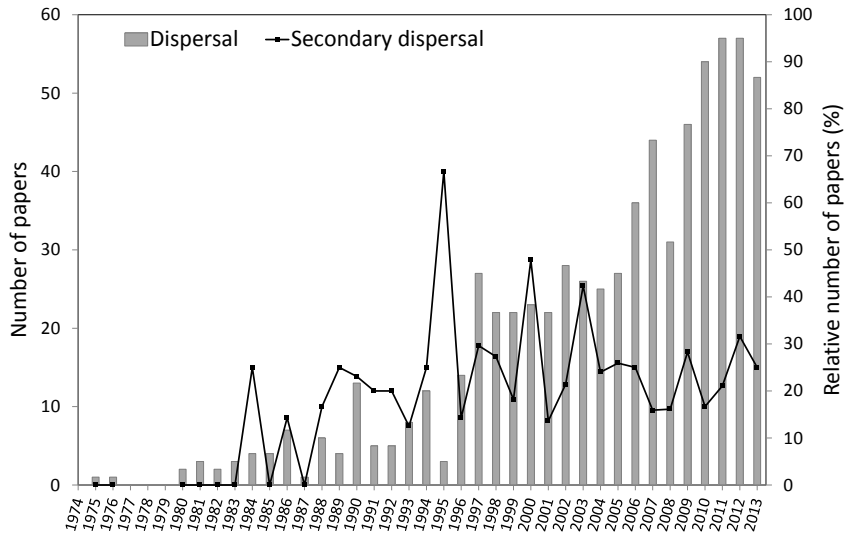

Figure 1. Temporal evolution of the total number of papers on seed fate and dispersal in drylands published between 1974 and 2013, along with the evolution of the relative number of papers focusing on secondary seed dispersal. Data were obtained from online keyword searches with Scopus database using the "All Document Type" option, date range from 1974 to 2013 and the following formulae in topics: (a) ("dispersal" or "seed fate" and "seed") and (arid or semiarid or semi-arid or dryland or "patchy vegetation" or "patchy ecosystem" or patchiness or mosaic or desert) for seed fate studies in general; (b) ("dispersal" or "seed fate" and "seed") and (arid or semiarid or semi-arid or dryland or "patchy vegetation" or "patchy ecosystem" or patchiness or mosaic or desert) and ("secondary dispersal" or "secondary seed dispersal" or "seed removal" or "seed movement" or "secondary seed movement" or "secondary movement" or "secondary process" or "post dispersal" or "postdispersal" or "seed bank" or "seedbank") for secondary seed dispersal studies.

pared to "fertility islands" with a privileged microclimate and improved soil properties (low solar radiation, low soil temperature, low evaporation rates, high concentration of resources, high fertility, high infiltration rates) within a matrix of poor and degraded bare ground (low fertility, high soil compaction, low water infiltration, high runoff volume, high wind and water erosion rates) (e.g. Schlesinger et al., 1990; Puigdefábregas and Sánchez, 1996; Cerdà, 1997; Bochet et al., 1998, 1999; Wilcox et al., 2003). Fertility islands may act as "nucleation" points facilitating the establishment of plant species that would otherwise be unable to establish (the process of "facilitation"; Callaway, 2007). In this context, seeds dispersed from the parent plant are scattered into a heterogeneous environment which is notoriously patchy in terms of the quality of sites suitable for seed germination and for the subsequent survival of seedlings (Schupp, 1995). Secondary dispersal may therefore be of vital importance for the recruitment stage of plants and have relevant ecological implications in the functioning of dryland ecosystems (Aguiar and Sala, 1997; Forget et al., 2002; Thompson et al., 2014). 


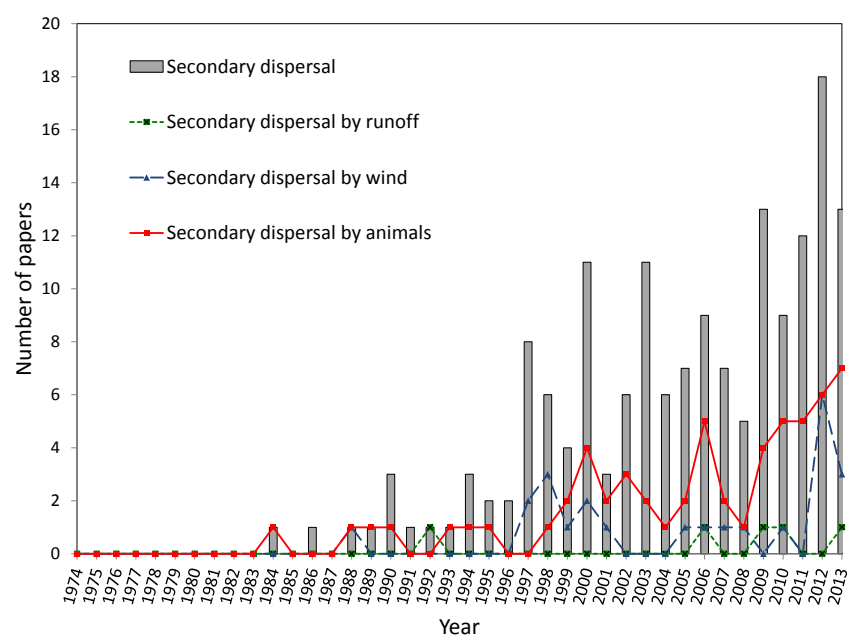

Figure 2. Temporal evolution of the total number of papers on secondary seed dispersal in drylands published between 1974 and 2013 , along with the total number of papers for the same time period specifically addressing secondary dispersal by animals, wind and overland flow. Data were obtained from online keyword searches with Scopus database using the "All Document Type" option, date range from 1974 until 2013 and the following formulae in topics: ("dispersal" or "seed fate" and "seed") and (arid or semiarid or semi-arid or dryland or "patchy vegetation" or "patchy ecosystem" or patchiness or mosaic or desert) and ("secondary dispersal" or "secondary seed dispersal" or "seed removal" or "seed movement" or "secondary seed movement" or "secondary movement" or "secondary process" or "post dispersal" or "post-dispersal" or "seed bank" or "seedbank"), adding (a) (runoff or run-off or erosion or "water transport" or "overland flow") for overland flow, (b) (wind or eolian) for wind, and (c) ("animal*" or biotic or ants or birds or rodents) for animals.

Even so, secondary dispersal has generally received little attention in the scientific literature, much less than primary dispersal (Chambers and Mc Mahon, 1994). An online literature compilation of 697 papers on the fate of seeds in drylands published in the last 40 years provides evidence of this clear unbalance (see Fig. 1 and reference list in the Supplement). During this time period, only a small proportion of the annually published papers, less than one-third, is related to secondary dispersal (Fig. 1). However, the evolution of the number of papers related to secondary seed dispersal in drylands shows a steady, even though fluctuating, increase from the mid-1990s until 2013 (Fig. 2), indicating that what happens to seeds once they have reached a first landing surface is becoming an increasingly important issue within the scientific community. Figure 2 also shows that the attention given to the main agents of secondary dispersal during the same time period is clearly uneven. Secondary dispersal by overland flow started to be documented later than secondary dispersal by wind and animals, and the annual rate of publications about secondary dispersal by overland flow has been very low since then.

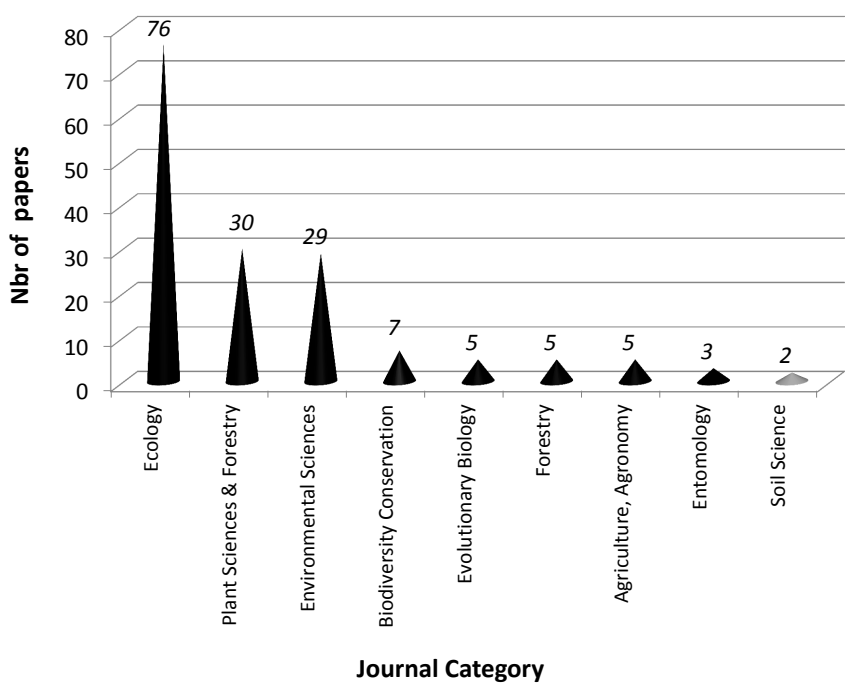

Figure 3. Total number of papers on secondary dispersal in drylands published between 1974 and 2013 and classified by journal categories. The graph underlines the anecdotal number of papers (2) published in soil-science-related journals (grey cone). Papers were assigned to a single main category even though in Scopus they could belong to several categories at a time. $N=162$. Papers were obtained from online keyword searches with Scopus using the "All Document type" option with the following formula: ("dispersal" or "seed fate" and "seed") and (arid or semiarid or semi-arid or dryland or "patchy vegetation" or "patchy ecosystem" or patchiness or mosaic or desert) and ("secondary dispersal" or "secondary seed dispersal" or "seed removal" or "seed movement" or "secondary seed movement" or "secondary movement" or "secondary process" or "post dispersal" or "post-dispersal" or "seed bank" or seedbank) in topics for period 1974-2013. From the 165 retrieved papers plotted in Fig. 2, three could not be classified, as information about journal category was lacking in Scopus.

Because seed fate issues lie at the interface between plant, animal and soil sciences, and because studies on secondary seed dispersal have seldom been published in soil-sciencerelated journals (Fig. 3), this paper seeks to bring readers, especially soil scientists, closer to understanding of the destiny of seeds in and on the soil. Understanding seed fate in the soil is not only a matter for the scientific community but is also crucial for the management of degraded ecosystems. Seeds are often one of the most important actors at the first stages of the restoration process, either through the influence of the soil seed bank, which plays a fundamental role in the composition of the future vegetation (Peco et al., 1998), or through the use of seeding or hydroseeding revegetation techniques in disturbed areas (e.g. Tormo et al., 2007, for roadslopes; Fernández et al., 2012, for burnt areas; Porqueddu et al., 2015, for quarries).

The main goals of this paper are (1) to offer an updated conceptual model of seed fate with a special focus on seed destiny in and on the soil; (2) to review studies on secondary seed dispersal by runoff and the ecological implications this 


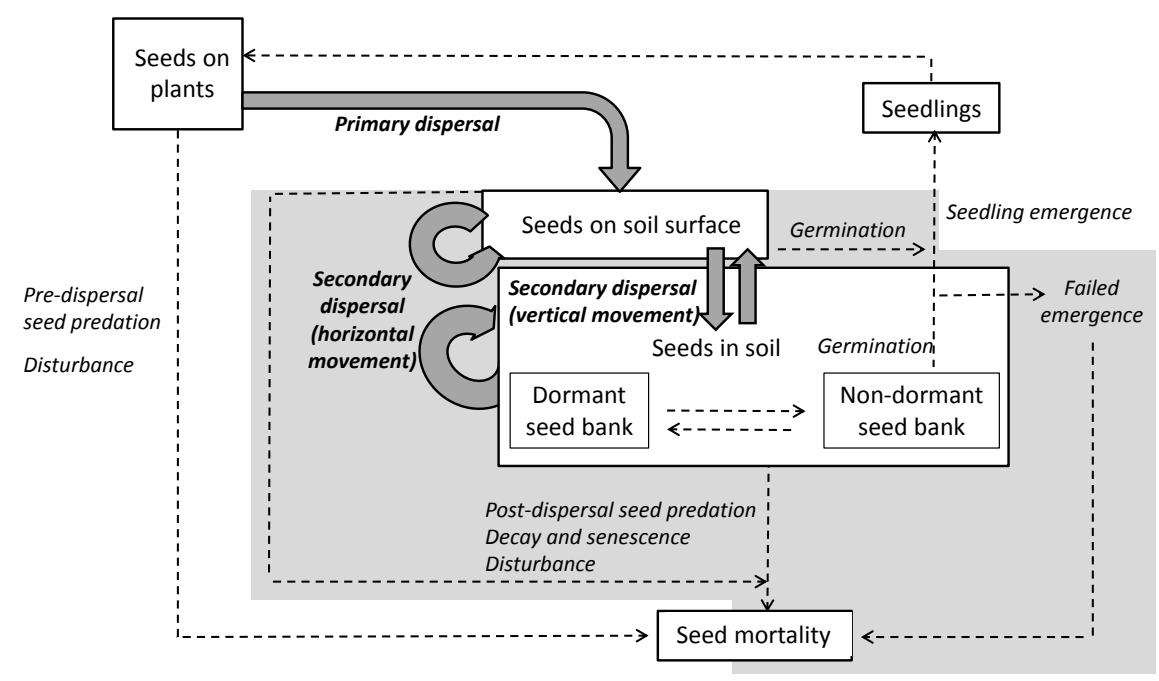

Figure 4. Conceptual model of seed fate in and on the soil (grey area). Rectangles represent seed states, dotted arrows indicate transitions between seed states, and processes are written in italics. Grey arrows indicate seed movements, and processes related to movement are in bold. After Schafer and Chilcote (1970), Fenner (1985), Chambers and Mac Mahon (1994) and Van der Wall et al. (2002). The term "seed" used throughout the model and the text represents the diaspore or unit of dispersal (seed with surrounding dispersal structures).

process has for the origin, spatial patterning and maintenance of patches in dryland ecosystems; and finally (3) to point out directions for future research. Our focus will be placed on drylands, because secondary dispersal has been recognized as a significant part of dispersal in environments with sparse vegetation (Nelson and Chew, 1977; Reichman, 1984; Chambers et al., 1991).

\section{Conceptual model of seed fates and movements in and on the soil}

Different models of seed fate have been proposed to describe the complex pathways populations of seeds might follow from seed production to seedling establishment. Since the early studies in the 1970s, models have progressively evolved and gained in complexity as new pathways of seed movement and fate were found (Harper, 1977; Fenner, 1985; Chambers and Mc Mahon, 1994; Baskin and Baskin, 1998; Vander Wall et al., 2002). On the basis of these previous models, Fig. 4 illustrates an updated conceptual model with a general description hereafter of the most likely alternative pathways a seed might follow from seed production to seedling establishment.

The model starts with the set of ripened seeds on the parent plant that have the potential to germinate (Fig. 4). Part of these seeds may be lost to death by means of pre-dispersal predation by animals or different types of disturbance affecting the parent plant (e.g. fire, waterlogging). Seeds that escape predation may be primarily dispersed via specific biotic or abiotic agents (animals, wind, rain, gravity) from the parent plant to a landing surface, the soil or any other type of surface (e.g. trunks, branches, litter, rocks). Once on the soil surface, seeds may experience different fates. First, they may germinate immediately if they have the chance to rest on a microsite with suitable conditions for germination and are non-dormant (i.e. physiologically active seeds). Second, seeds may be lost to death by post-dispersal predation (ants, rodents or birds) or decay due to pathogen attacks or senescence (Hulme, 1998). Third, seeds may rest at the initial point of deposition and remain on the soil surface for a short or long period, depending on the dormancy state of the seed and the occurrence of favourable conditions for germination. Seed dormancy has to be broken by the agents responsible for dormancy alleviation (time, temperature, moisture) before seeds can germinate in favourable environmental conditions (e.g. light, improved oxygen levels). Finally, seeds may be subjected to secondary dispersal processes and moved to new sites via horizontal and/or vertical seed movements.

Concerning vertical movements, seeds may be incorporated from the soil surface into the soil in either a nondormant or a dormant state and form the soil seed bank (Thompson et al., 1993; Traba et al., 2004). Seeds entering into cracks at the soil surface and seed burial by small burrowing animals or by local accumulation of sediments may enhance vertical seed movements (Chambers and Mac Mahon, 1994; Chambers, 2000). Non-dormant seeds may germinate immediately once they have entered the soil in the case of favourable environmental conditions for germination, and give rise to new seedlings if they are able to emerge above the soil surface. Dormant seeds may remain in the soil for long periods, waiting first for dormancy alleviation and then for the occurrence of favourable environmental conditions for germination. Seeds may also be moved vertically by animals in the opposite direction, from the soil seed bank 
to the soil surface, or be brought to the soil surface by a different kind of disturbances (e.g. runoff, wind).

Seeds on or in the soil may also be moved horizontally to new locations by different biotic (animals) or abiotic (often wind, runoff and gravity) agents and experience there the same fates as the ones described for seeds landing for the first time on the soil surface after primary dispersal.

The following sections will focus on seed movements caused by runoff and their implications for vegetation establishment and for the spatial organization and functioning of arid and semiarid patchy ecosystems.

\section{Seed removal by runoff: a review}

\subsection{Outcomes of seed removal by runoff: seed loss or seed redistribution?}

In drylands, rainfall is often concentrated into a small number of intense high-erosivity events that are responsible for more than $70 \%$ of the soil loss rates (Wainwright, 1996; MartínezCasasnovas et al., 2005). Under these conditions, seeds in the seed bank or resting on the soil surface after primary dispersal are exposed to overland flow, especially in bare patches where high rates of runoff and sediment transport have been reported (Cerdà, 1997; Calvo-Cases et al., 2003; Boix-Fayos et al., 2005; Bochet et al., 2006).

The first evidence that runoff may act as a vector of seed transport was indirect and based on observations of seed dispersal strategies in runoff-prone areas (Friedman and Orshan, 1975; Friedman and Stein, 1980), comparisons of plant distribution with different dispersal mechanisms between slopes and wadis (Reichman, 1984), or descriptions of seed distribution patterns in different microhabitats (Ellner and Schmida, 1981) in desert ecosystems worldwide. In the 1990s, it was argued that seed removal by runoff led to seed loss and might explain the lack or scarcity of vegetation on semiarid and arid hillslopes (Debusche and Lepart, 1992; Francis, 1991; Chambers and Mac Mahon, 1994). Although frequently invoked, this assumption was not empirically checked until the pioneering studies of García-Fayos and his collaborators about seed transport by runoff flow. Their studies aimed at quantifying rates of seed losses in order to determine whether seed removal by runoff could explain the lack of vegetation in highly eroded badland slopes of southeastern Spain (García-Fayos and Recatalà, 1992; García-Fayos et al., 1995; García-Fayos and Cerdà, 1997; Cerdà and García-Fayos, 1997, 2002; Table 1). In these stressful environments characterized by extreme rates of erosion (Gallart et al., 2013), seed inputs into the soil seed bank due to seed fall were greater than the seed outputs due to removal by erosion (21 and $5.6-12.6 \%$ of the soil seed bank, respectively), thus resulting in a positive seed balance at the catchment scale (GarcíaFayos and Recatalá, 1992; García-Fayos et al., 1995). In the same badland area, seed losses were quantified in several experimental studies under simulated rainfall at $55 \mathrm{~mm} \mathrm{~h}^{-1}$ over $0.24 \mathrm{~m}^{2}$ field plots with different slope angles and rainfall durations (Table 1). In all cases, average seed losses by runoff for the whole set of species were low (4, 0.4-7.9 and $<13 \%$ according to the experimental conditions of Cerdà and García-Fayos, 1997; García-Fayos and Cerdà, 1997; and García-Fayos et al., 1995, respectively) and seed loss rates of individual species did not in any case exceed $25 \%$ (GarcíaFayos and Cerdà, 1997). These results were in agreement with average seed losses obtained under natural conditions (García-Fayos et al., 1995) and also under laboratory conditions, where only $11 \%$ of the seeds resting on an artificial surface were lost in average under simulated rainfall of similar intensity (Cerdà and García-Fayos, 2002, Table 1). Moreover, the relationship between the rate of seed loss and the amount of runoff proved to be positive and exponential in these badland ecosystems (García-Fayos and Cerdà, 1997). According to all these results, it was concluded that seed loss by overland flow was not the key factor explaining the absence of vegetation on badland slopes as the probability of rainfall events of higher intensity and duration is low. Other possible alternative causes were suggested and further investigated, such as scarce water availability for plants, high salinity and the interaction of these latter factors with seed germination (García-Fayos et al., 2000; Bochet et al., 2009).

Recently, similar studies were carried out to test the same hypothesis in the Chinese Loess Plateau, i.e. the scarcity of vegetation as a consequence of seed removal by runoff (Jiao et al., 2011; Han et al., 2011; Wang et al., 2013; see Table 1). Similar results to that documented in the Spanish badland areas were obtained, since no seed losses were recorded in small bins filled with soils collected from the field at a similar rainfall intensity $\left(50 \mathrm{~mm} \mathrm{~h}^{-1}\right)$ and different slope angles (Jiao et al., 2011; Han et al., 2011). However, the total amount of seeds lost by runoff was closely related to runoff volume and sediment yield and average seed losses reached 32.6 and $66.0 \%$ values at rainfall intensities of 100 and $150 \mathrm{~mm} \mathrm{~h}^{-1}$, respectively. Seed loss rates up to $100 \%$ were described for some species in a similar laboratory experiment under $30 \mathrm{~min}$ simulated rainfall at $120 \mathrm{~mm} \mathrm{~h}^{-1}$ (Wang et al., 2013). However, because rainstorm intensities heavier than $50 \mathrm{~mm} \mathrm{~h}^{-1}$ are very occasional in the Chinese Loess Plateau, Jiao et al. (2011) concluded that seed losses by runoff could not explain the scarcity of vegetation in the Chinese Loess Plateau as it had been already pointed out for the semiarid badland slopes of southeastern Spain (García-Fayos and Recatalà, 1992; García-Fayos et al., 1995).

The generally low rates of seed losses described in these studies may be due, in part, to the burial of seeds in the soil after being trapped or at the time they get covered by local accumulations of sediments transported by overland flow (Chambers et al., 1991).

Moreover, caution is needed when it comes to interpreting these data in terms of seed losses for the ecosystem. Several authors have evidenced the limitations of extrapolating small-plot erosion measurements - and their associ- 


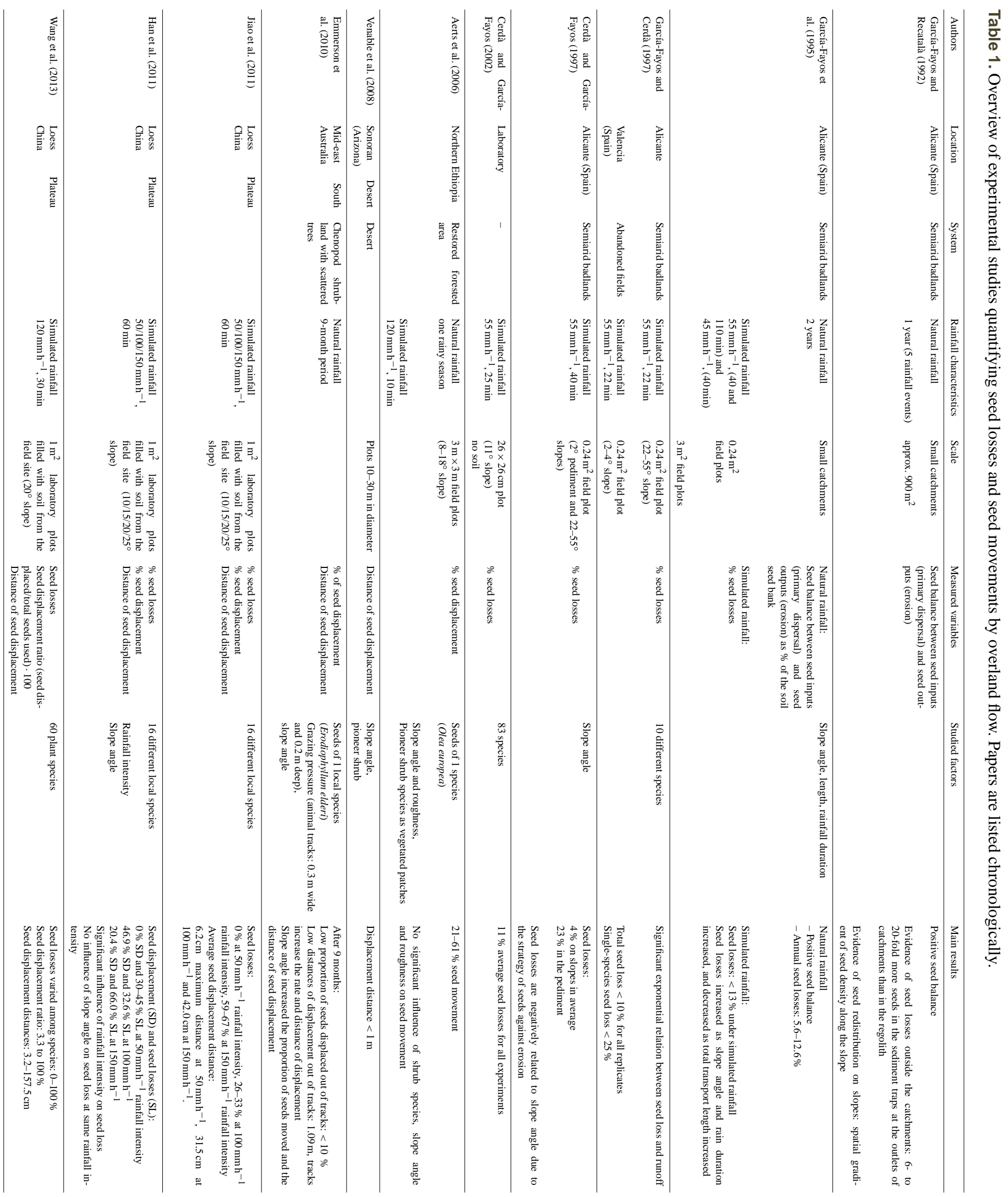


ated processes - to larger areas, because different processes act at different scales (splash, interrill, rill and gully erosion) and thresholds and non-linear processes are involved at specific scales and at the connection between scales (Govers, 1991; Cammeraat, 2002). Therefore, seed losses by overland flow measured at the plot scale in small areas $\left(0.24\right.$ to $3 \mathrm{~m}^{2}$, Table 1) and over short distances relative to the inter-patch spacing in patchy systems $(<2 \mathrm{~m}$, Table 1$)-$ as the ones reported in the aforementioned studies - could be considered seed displacements or seed translocations to new sites at the hillslope scale. In this respect, another body of research suggested that seeds transported by overland flow are not lost but redistributed along the slopes through downslope seed movements from one location to another. Aerts et al. (2006) reported that 21 to $61 \%$ of the seeds of the species Olea europea were translocated to new sites under simulated rainfall within $3 \mathrm{~m} \times 3 \mathrm{~m}$ plots placed in restored forested areas in Ethiopia. Similarly, Jiao et al. (2011) and Han et al. (2011) described that $30-45,46.9$ and $20.4 \%$ of the seeds were moved from one site to another site inside a $1 \mathrm{~m}^{2}$ and $2 \mathrm{~m}$ long laboratory experimental bin at intensities of 50,100 and $150 \mathrm{~mm} \mathrm{~h}^{-1}$, respectively, without being exported outside the bin. Using the same experimental setup, Wang et al. (2013) measured an average distance of $157.5 \mathrm{~cm}$ corresponding to seed redistribution by runoff within a $2 \mathrm{~m}$ long bin, which was longer than the length of the plots used by Cerdà and García-Fayos (1997) and García-Fayos and Cerdà (1997) to quantify seed loss rates. Thus, whether seeds are lost or redistributed may be a matter of scale and more studies quantifying seed transport by runoff are needed at larger scales, where processes other than sheet erosion may also take part in seed transport (e.g. rill and gully erosion). The only study that quantified seed transport by runoff at the slope and catchment scales in semiarid ecosystems gives evidence of both outcomes: seed loss and seed redistribution (García-Fayos and Recatalà, 1992). On the one hand, these authors observed an increasing seed density in the downslope direction from the top to the bottom part of the slope that supports, at least in part, the hypothesis of seed redistribution along the slope. On the other hand, the 6- to 20-fold difference in seed concentration at the outlets of catchments and in the regolith demonstrates that seed losses out of the system also occur.

\subsection{Factors influencing seed removal by runoff}

\subsubsection{External factors}

In some of the aforementioned studies, it was also claimed that several factors influence the severity of seed transport by runoff (Table 1). A strong relationship was found between the magnitude of seed transport by runoff and rainfall and slope characteristics. Similar to what happens to soil particles (Govers, 1989; Parsons et al., 1993; de Vente and Poesen, 2005; Boix-Fayos et al., 2006), seed losses increased as slope angle (García-Fayos et al., 1995; Jiao et al., 2011; Han et al.,
2011; but Cerdà and García-Fayos, 1997) and rain duration and intensity increased (García-Fayos et al., 1995; Jiao et al., 2011; Han et al., 2011), but it decreased with soil surface roughness (Reichman, 1984; Chambers, 2000; Aerts et al., 2006; Isselin-Nondedeu et al., 2006; Isselin-Nondedeu and Bédécarrats, 2007) and with total slope length (García-Fayos et al., 1995). Soil texture also influenced seed losses, since larger soil particles increased the amount of seeds trapped in the soil (Chambers et al., 1991; Traba et al., 2006). Results of these studies also suggested that seed characteristics could obscure the relationships between runoff and seed losses and were therefore further investigated (Friedman and Orshan, 1975; García-Fayos et al., 1995; Cerdà and García-Fayos, 1997; García-Fayos and Cerdà, 1997; Han et al., 2011).

\subsubsection{Seed characteristics}

A body of research aimed at understanding the relationships between seed morphology and seed removal by runoff under the hypothesis that single seeds should behave in the same way as soil particles regarding erosion and overland flow (García-Fayos and Cerdà, 1997). Thus, because soil particle size and shape are considered good predictors of soil particle susceptibility to removal (Kirkby, 1980; Poesen and Savat, 1980; Parsons et al., 1991) and spherical soil particles are more susceptible to be removed by overland flow than plate-shaped ones (Winkelmolen, 1971), similar trends were expected for seeds. Models based on laboratory rainfall simulation experiments showed that seed size was the main factor explaining seed removal, whereas the shape became important only when the seed size exceeded a specific threshold value which depended on the experimental conditions $(50 \mathrm{mg}$ value in the experimental conditions of Cerdà and GarcíaFayos, 2002; García-Fayos et al., 2010). This rule was valid for spherical seeds, whereas no seed removal occurred from the threshold value onwards for flat-shaped seeds heavier than $50 \mathrm{mg}$. The relevance of seed size and shape in the severity of seed removal by runoff was later corroborated under rainfall simulation conditions for species living in the Chinese Loess Plateau (Wang et al., 2013) and under field conditions in the French Alps (Isselin-Nondedeu and Bédécarrats, 2007; Isselin-Nondedeu et al., 2006). In general terms, likewise soil particles, small and rounded seeds proved to be more susceptible to removal by runoff. However, further investigations demonstrated that the influence of seed characteristics on seed removal was more complex as initially thought, because seed susceptibility to be removed by runoff could be affected by other properties, such as the presence of seed appendages (hairs, wings, awns) or the ability of seeds to secrete mucilage, a sticky gel that forms around the seed once the seed comes in contact with water and glues the seeds to the ground (García-Fayos, 2004; García-Fayos et al., 2010). The presence of appendages reduced seed susceptibility to be removed by overland flow as regards seeds of similar weight that did not have appendages (García-Fayos, 2004). 
Similarly, species with light seeds $(\leq 0.7 \mathrm{mg}$ ) able to secrete mucilage experienced $10 \%$ lower losses than the seeds with similar mass that did not secrete mucilage (García-Fayos, 2004; García-Fayos et al., 2010).

Although less studied, seed buoyancy is another seed trait that may also influence seed movement in surface water since buoyant seeds will be able to float and move with overland flow when water depth is higher than the seed size (Thompson et al., 2014).

Finally, some seed traits enhance the incorporation of seeds into the soil column and therefore decrease the seed susceptibility to be removed by overland flow (Chambers et al., 1991). Small seed size and a lack of appendages are relevant morphological attributes for incorporation of a seed into the soil (Chambers et al., 1991), even though specialized appendages such as hygroscopic awns can facilitate seed burial (Peart and Clifford, 1987). However, if seeds are buried too deeply, especially small seeds, they can fail to act as functional seeds for the ecosystem (Traba et al., 2004).

\section{Long-term and large-scale ecological implications of seed removal by runoff in arid and semiarid ecosystems}

\subsection{Seed removal by runoff: an ecological driver of vegetation}

\subsubsection{Seed removal by runoff shapes plant community composition (community level)}

Although average seed losses by runoff measured in dryland plant communities were generally low, specific seed losses rates varied strongly among species within a plant community (García-Fayos et al., 1995; Jiao et al., 2011; Wang et al., 2013) as a result of the interaction between the seed morphology and overland flow. Consequently, seed removal by runoff is expected to contribute to the final plant composition of eroded environments.

Several recent studies aimed at exploring whether soil erosion, through its effects on seed removal by runoff, could explain the composition of plant community on eroded slopes in dryland ecosystems (Bochet et al., 2009; García-Fayos et al., 2010, 2013; Wang et al., 2013; Engelbrecht et al., 2014). García-Fayos et al. (2010) found that the average susceptibility of seeds to be removed by runoff was lower for plant communities of species living on steep slopes than for plant communities developing in flat areas in a semiarid area of eastern Spain (but see Wang et al., 2013, for a similar study in the Chinese Loess Plateau). Moreover, the proportion of species possessing a trait able to improve seed resistance to removal by runoff (mucilage secretion or presence of hygroscopic awns) varied between plant communities, with a higher proportion of seeds displaying anchorage mechanisms on the eroded slopes when compared with the flat areas (Bochet et al., 2009; García-Fayos et al., 2013). This propor- tion was also correlated with soil properties associated with runoff generation (García-Fayos et al., 2013).

After analysing the physical properties of seeds from species living in different deserts of the world, Thompson et al. (2014) observed that all the species analysed except one produced seeds with lower densities than water, being therefore able to float and be transported by overland flow. However, before any conclusion can be stated about the role of erosion in this association, these results should be corroborated with data from species living in areas where overland flow is absent.

Overall, these results provide evidence that erosion through its selective pressure on seeds by overland flow and the interaction of this latter with seed morphology - filters plant species at the community level from the very first stages of the plant life. The role of erosion as an ecological driver that shapes the composition of plant communities had already been highlighted in previous studies in arid and semiarid environments (Guàrdia et al., 2000; GuerreroCampo and Montserrat-Martí, 2000, 2004; García-Fayos and Bochet, 2009; Bochet et al., 2009; Jiao et al., 2009). However, relatively little attention had been paid to the effect of erosion on seeds (mainly seed transport and germination) as compared to later stages of the plant life (seedlings and adult plants; de Luís et al., 2005; Tsuyuzaki and Haruki, 2008; Wang et al., 2014), even though seed stage is one of the most critical phases in vegetation development (García-Fayos and Cerdà, 1997).

\subsubsection{Seed removal by runoff selects for seed traits and for adaptative plant strategies (species level)}

As already mentioned and further explained in Sect. 3.3, seed redistribution by runoff can provide seeds with a second chance to lie in a more favourable site for seed germination and seedling establishment in arid and semiarid patchy ecosystems. In some cases, however, seed removal by runoff can be responsible for the loss of seed germination opportunities when seeds of plants inhabiting eroded hillslopes are moved downhill to less favourable sites where seeds can get deeply buried or suffer from strong competition with other seedlings or pre-established plants in water- and nutrientrich soils (Cantón et al., 2004). As a result, plants may have evolved strategies to escape from massive seed loss to unsafe sites (Engelbrecht, 2014). In this respect, the possible adaptative value of mucilage secretion under desert conditions as a mechanism preventing seed removal by runoff was initially proposed by Ellner and Shmida (1981) and recently explored by Engelbrecht et al. (2014). These authors analysed at the species level whether mucilage secretion can be considered an adaptative response to soil erosion in plant species inhabiting semiarid environments. More specifically, they related the amount of mucilage secretion by seeds to the severity of the two main sub-processes whereby water erosion acts on soil particles and presumably also on seeds (i.e. splash 
detachment and overland flow transport). The amount of mucilage secreted by seeds of the species Fumana ericifolia was directly proportional to their resistance to raindrop impact and was, moreover, positively related to the intensity of the erosive processes that the plants experienced in the field in semiarid Mediterranean shrublands. Furthermore, according to overland flow transport, all the seeds resisted the strength of runoff irrespective of the amount of mucilage they produced. However, the effect of mucilage secretion in the rate of seed removal by erosion was species-dependent, and Engelbrecht et al. (2014) concluded that their results only partially supported the idea that seed anchorage mechanisms to the ground, such as mucilage secretion, can be considered an adaptation to the hazards that erosive conditions impose on plants that inhabit open dry habitats.

\subsection{Seed removal by runoff influences the origin, spatial pattern and maintenance of patches in arid and semiarid ecosystems}

A few studies have investigated the long-term and largescale ecological implications of seed removal by runoff in the structure and functioning of arid and semiarid ecosystems worldwide (e.g. Aguiar and Sala, 1997, 1999; Schurr et al., 2004; Puigdefábregas, 2005; Aerts et al., 2006; Saco et al., 2007; Venable et al., 2008; Emmerson et al., 2012; Thompson et al., 2014). Figure 5 illustrates schematically these implications on the basis of the available literature described hereafter.

Various hypotheses have been put forward to explain the origin, spatial distribution and maintenance of patches in arid and semiarid ecosystems (e.g. Dunkerley and Brown, 1995; Pueyo et al., 2008; Kéfi et al., 2008). Variations in slope angle and the presence of local accumulations of organic debris and sediments, and of depressions in the soil surface, as well as rocks or ant mounds on nearly bare slopes, have been reported as possible physical obstacles to overland flow that can enhance local germination of entrapped seeds and further establishment of seedlings (e.g. MacFadyen, 1950; Reichman, 1984; Aguiar and Sala, 1997; Chambers, 2000; Venable et al., 2008). Alternatively, seed anchorage mechanisms (mucilage and hygroscopic awns) can also be instruments whereby new patches of vegetation originate on eroded hillslopes (García-Fayos et al., 2013).

Whatever their origin, once a seedling establishes from a germinated seed, it interacts with overland flow intercepting the downslope movement of water, sediments and nutrients, locally improving the fertility and water availability below the plant canopy and favouring the growth of the plant and the patch (Cerdà, 1997; Bochet et al., 1999; Puigdefábregas, 2005). As a result, the system becomes heterogeneous in terms of the quality of sites suitable for seed germination, the subsequent survival of seedlings, and the resources available for plant growth (Schupp, 1995). Spatial heterogeneity is promoted and maintained by complex interactions between patches and overland flow in a self-organizing process ( $\mathrm{Ri}$ etkerk et al., 2004).

These complex interactions give rise to two main spatial vegetation patterns that can be found worldwide: on the one hand, "spotted" patterns are represented by vegetation clusters that are irregular in shape and surrounded by bare soil (Aguiar and Sala, 1999) and, on the other hand, "banded" patterns form densely vegetated stripes parallel to the contour lines that alternate with almost bare soil stripes on very gentle slopes (Valentin et al., 1999). Nowadays, there is general agreement that surface runoff is a key control on the appearance of such vegetation patterns and that the dynamics of runon-runoff areas is the main driver of the spatial organization of such patterned ecosystems (e.g. Valentin et al., 1999; Tongway and Ludwig, 2001). Recently, Moreno-de las Heras et al. (2011) recognized the importance of the directional downslope redistribution of surface runoff and sediments in the periodicity of the patch-size distribution in banded landscapes in Australia. More specifically, they argued that the co-existence of long-distance negative vegetation-water feedbacks (including downslope redistribution of runoff and plant competition for water) and short-distance positive feedbacks (local plant facilitation) are responsible for the regular patterns of the vegetation. Although seed dispersal and fate should play a crucial role in these feedback mechanisms (Kéfi et al., 2008; Pueyo et al., 2008), the role of surface runoff, as a vector of seed transport, in the functioning and maintenance of patchy ecosystems has been poorly documented.

The existing literature, based on empirical as well as theoretical studies, mainly supports the idea that a patch-to-patch transfer of seeds occurs that helps in maintaining the patchy structure of the vegetation. The patch-to-patch transfer of seeds results from a combination of a "directed" dispersal of seeds through runoff to areas with favourable conditions (Howe and Smallwood, 1982) and the high plant capacity to trap seeds. Aguiar and Sala (1997) provided strong empirical evidence that high seed transit due to secondary dispersal agents (mainly wind but also water) occurred in bare inter-patch areas in the Patagonian steppe of Argentina, at the same time as they reported high rates of seed trapping by the vegetation, whereas bare areas were unable to retain almost any seed. Similar results showing the patchy distribution of the seed bank and its concentration mainly in vegetated patches have been described in the Sonoran Desert of Arizona (Reichman, 1984) and in banded landscapes of Mexico and Niger (Mauchamp et al., 1993; Seghieri et al., 1997). Moreover, Aguiar and Sala (1997) observed that overlapping of high seed densities with the availability of safe sites gave rise to successful recruitment near the vegetated patches and helped maintaining or even reinforced the current spatial heterogeneity of the system. In banded landscapes, seeds trapped by the vegetation are present throughout the bands, but the better water availability at the upslope edge of bands, and the smaller runoff volume passing 
(a)

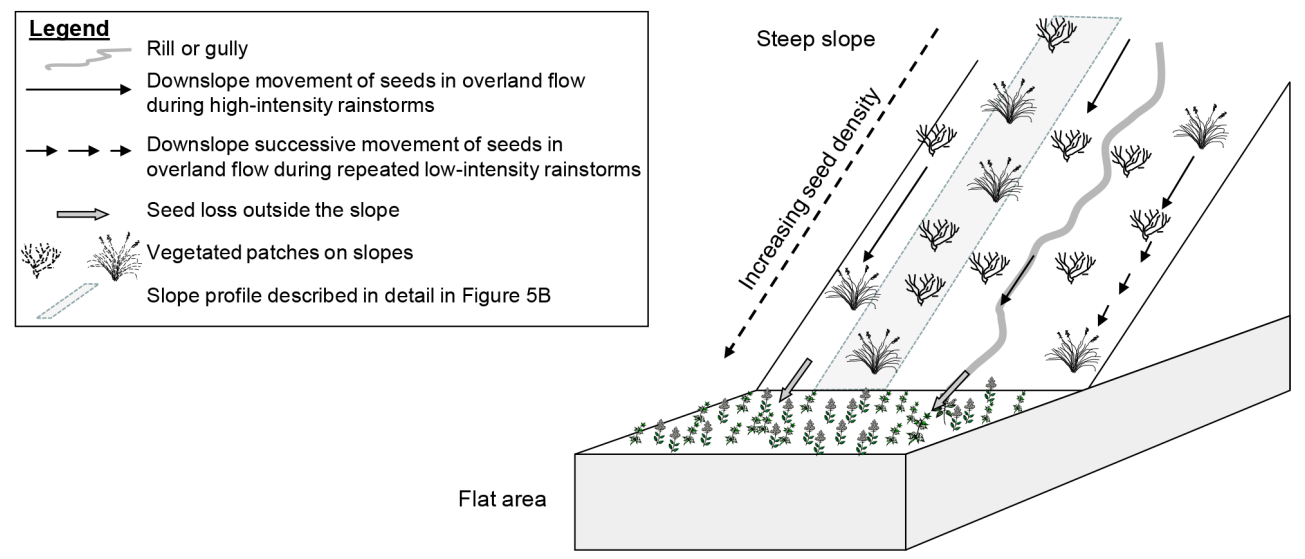

(b)

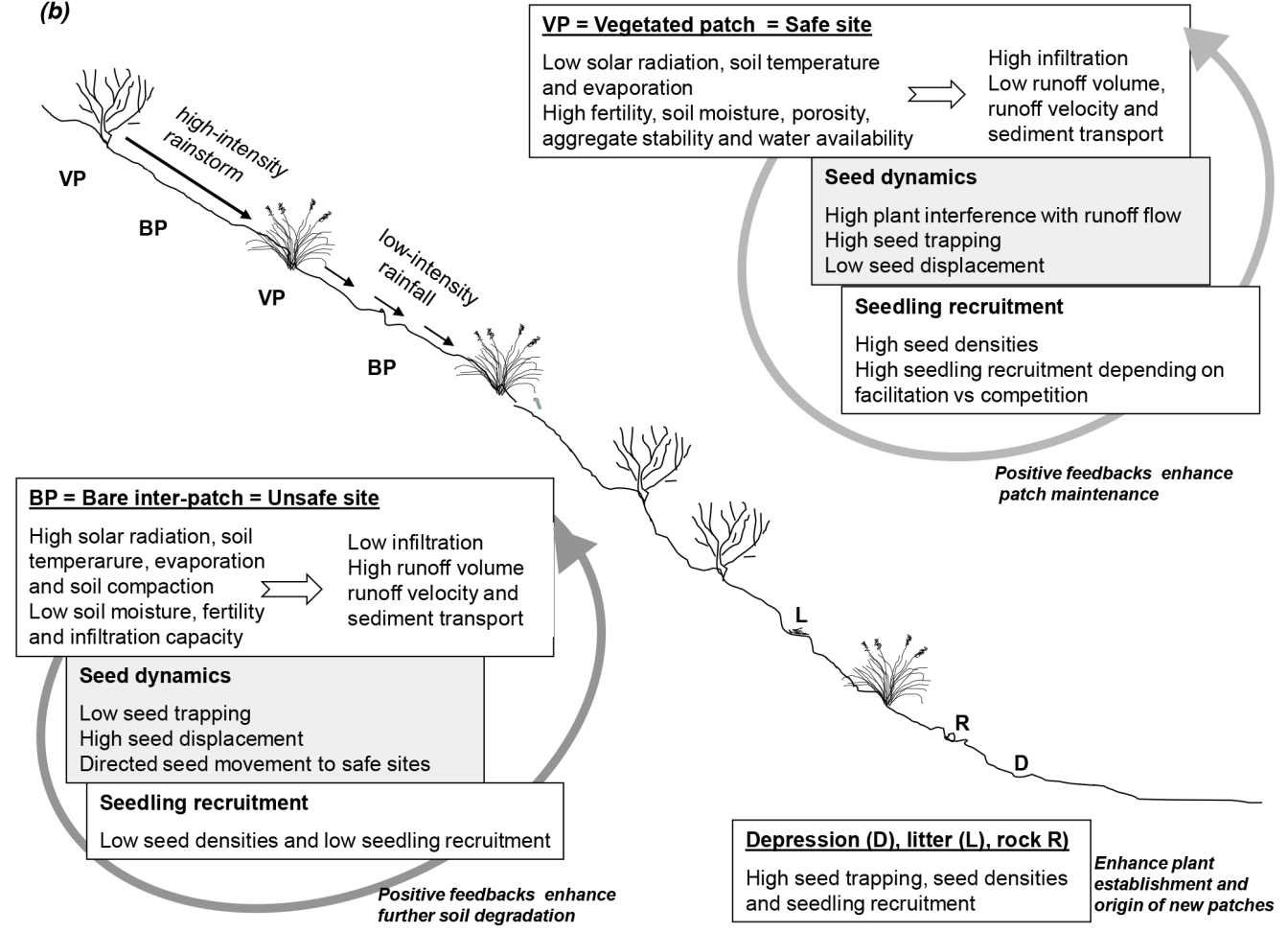

Figure 5. Schematic figure of seed fate in overland flow at the (a) slope scale and (b) patch scale (patch-to-patch transmission of seeds). The figure represents how the spatial pattern of the vegetation influences seed distribution and seed fate and how, in turn, seed fate influences the origin and maintenance of patches in arid and semiarid patchy ecosystems.

through to the downslope edge, leads to the colonization of the upslope edge by pioneer species and to the progressive death of plants at the downslope edge (Seguieri et al., 1997; Valentin et al., 1999). A possible outcome that has been inferred from these observations by many authors, and which remains a controversial topic today, is that the vegetation patterning migrates progressively upslope (Thiéry et al., 1995;
Montaña et al., 2001; Deblauwe et al., 2012). Nevertheless, the use of new technologies in the study of slow ecosystem dynamics (e.g. high-resolution satellite images and airborne photographic surveys) provided recently unequivocal photographic evidence of marked upslope migration for different dryland areas exhibiting banded patterns worldwide (e.g. northeastern Chihuahuan Desert, Somalian Haud and 
Mediterranean steppes of eastern Morocco; Deblauwe et al., 2012). In the same study, however, Deblauwe et al. (2012) stated that these dynamics which proved to be widely influenced by weather regimes cannot be considered as systematic because migration was undetectable at the available image resolution in other banded systems they investigated (e.g. central Australia, western New South Wales). The reasons causing some banded patterns to move fast and others to be static are still elusive. Deblauwe et al. (2012) provide a review of some possible mechanisms that may explain these differences, including seed translocation by overland flow. In a recent model, Saco et al. (2007) related the migrating or stationary condition of bands to the dispersal of seeds by overland flow. They found that the anisotropic redistribution of seeds by surface flow downslope might prevent the bands from travelling upstream, whereas isotropic seed dispersal mechanisms might be responsible for upslope band migration. However, empirical studies investigating seed fluxes are needed to validate this model and the possible migrationimpeding role of seed redistribution. As regards banded patterns, the dynamics of spotted vegetation might be more complex, as the former usually act as closed hydrological systems and the latter highly depends on the connectivity of bare areas (Saco et al., 2007). Recent studies demonstrate that it is not only the extent to which vegetation patches prevail on a slope (Parsons et al., 1996; Wainwright et al., 2000; Bochet et al., 2000; Puigdefábregas, 2005) but also the connectivity of bare areas that influences hydrological processes such as runoff and sediment transport (Bautista et al., 2007; Puttock et al., 2013). Connectivity has the advantage, as regards vegetation structure, to provide an explanatory link between abiotic and biotic components to determine the hydrological and ecological function of the system (Turnbull et al., 2008, 2010). In their ecohydrological conceptual framework, Turnbull et al. (2008) hypothesized that structural connectivity - which determines the amount and extent of abiotic and biotic resource redistribution - is the key determinant of the connectivity of ecological and hydrological processes, and thus of the functional connectivity, which includes water, sediment and seed movement within the landscape. Thompson et al. (2014) recently developed a theoretical model of seed dispersal processes by runoff where hydrological connectivity was considered as an influencing variable on seed movement by overland flow. The model supported the hypothesis of a patch-to-patch transmission of seeds under specific conditions of rainfall and connectivity between patches. According to the model, either long and intense storms heavy enough to trigger seed movement and to induce transport distances comparable to the inter-patch bare spacing or repeated storms allowing repeated seed transport are required in combination with high topographical and hydrological connectivity to generate a patch-to-patch transport of seeds.

In the reviewed literature, however, a few empirical studies do not support the patch-to-patch hypothesis. These studies highlight the absence of seed movement from the bare inter- patch areas to the vegetation patches in combination with a low seed trapping capacity by the vegetation (Aerts et al., 2006) or with short dispersal distances relative to the pattern of spatial heterogeneity (Venable et al., 2008; Emmerson et al., 2010, 2012). The authors concluded that successful recruitment of the species used in these experiments could not rely on seed transport by runoff but depended on other mechanisms such as primary dispersal (Aerts et al., 2006) or the temporal delay of germination (Venable et al., 2008; Siewert and Tielborger, 2010).

Overall, in arid and semiarid patchy ecosystems, seed fate in overland flow seems to be determined by the spatial organization of the vegetation and by the hydrological connectivity of bare patches that appear to influence the origin and maintenance of patches (Fig. 5). A range of abiotic as well as biotic processes contribute to the structure and functioning of these ecosystems, whereby seed establishment influences overland flow and, in turn, overland flow - through the directed transport of seeds between connected vegetated patches - influences vegetation establishment and patch dynamics (Moreno-de las Heras et al., 2011).

\section{Directions for future research}

This review shows that repeated seed transport by overland flow leads to either seed losses from the system or the redistribution of seeds within the system through short seed movements. Because seed losses by runoff were generally low in field conditions, we should be aware of the risks of over-interpreting the role of seed losses by erosion in the structuring of plant communities (García-Fayos et al., 2010). Possible reasons explaining the low rates of seed losses reported in the literature should be further investigated besides seed burial in the soil through vertical movements (Chambers and Mac Mahon, 1994; Chambers, 2000) and the lack of data describing seed losses caused by erosion processes acting at larger spatial scales and responsible for the largest proportions of soil loss in these ecosystem (but see Espigares et al., 2011).

Conversely, seed removal in terms of seed displacements to short distances proved to play an important role in the vegetation composition and spatial patterning of arid and semiarid patchy ecosystems, through the interaction between vegetated patches, overland flow carrying the seeds downslope, and seed traits. Thus, the directed short-distance displacement of seeds to suitable sites where seeds are preferentially trapped by the vegetated patches results in a "patch-to-patch transport" of seeds through well-connected bare areas, which helps in maintaining the patchiness of the system.

Since recent models have related the origin and maintenance of patchiness to the lack of long-distance dispersal syndromes for plants living in arid and semiarid ecosystems (Pueyo et al., 2008; Kéfi et al., 2008), an exciting challenge for the future would be to link these models to field data 
of seed removal by runoff. The idea that dispersal is spatially limited in arid and semiarid ecosystems (Ellner and Schmida, 1981) and that seeds are removed by runoff in such ecosystems may not be as contradictory, as it has been shown that seed removal acts mainly through short seed displacements within the system. Therefore, more empirical studies are needed to understand the relevance of seeds moved by runoff in the broader context of long-distance negative feedbacks (spatial redistribution of surface runoff and plant competition for water) and short-distance positive feedbacks (local plant facilitation) that seem to control the functioning of these ecosystems (Pueyo et al., 2008; Kéfi et al., 2008; Turnbull et al., 2008).

Arid and semiarid ecosystems are experiencing increasing pressures as a result of human activities and climate change, and future scenarios of climate change predict changes in vegetation (type, cover and spatial distribution; Specht and Specht, 1995) and rainfall distribution (higher intensive rainstorms; Nearing et al., 2004), leading both of these to more intense erosion events. In this context, we should be able to understand how these changes might influence seed movements in overland flow and their consequences for the composition, structure and functioning of these ecosystems. Under such scenarios, the complex feedbacks between the spatial distribution of the vegetation, runoff and erosion that influence the spatial redistribution of abiotic and biotic resources within the landscape may experience severe changes (Turnbull et al., 2008, 2011). For example, a reduced or altered distribution of the vegetation and an increased connectivity of bare runoff-generating areas would result in higher velocities and erosive forces of the flow and, consequently, a higher flow capacity to transport sediment, nutrients and also seeds. It is suggested that when the internal system stabilizing feedbacks are altered by exogenous forces, the resilience of the ecosystem (i.e. its capacity to absorb disturbance and reorganize) changes and the system becomes more sensitive to experience non-linear functional dynamics and cross critical thresholds (Turnbull et al., 2008, 2011). Therefore, there is an urgent need for new experimental studies addressing the feedbacks between structure and function and abiotic and biotic components of systems that may help to predict future changes in semiarid ecosystems under the scenarios of climate change.

Understanding the fate of seeds in overland flow is also a critical issue for the successful restoration of severely eroded slopes (such as road embankments, roadcuts, mine spoils, burnt areas). The advances in the knowledge of significant seed characteristics able to prevent seed removal by runoff and of the trapping efficiency of plants, litters and depressions in the soil surface and their consequences on successful plant recruitment are of potential great benefit to practitioners and policy makers involved in road slope restoration (Rey et al., 2005). The use of recently developed models combining overland flow dynamics with seed fate and erosion can also be of great benefit in designing restoration projects of plant communities on eroded hillslopes (Thompson et al., 2014). However, great effort should be made within the scientific community to improve ways to quickly and efficiently transfer this available knowledge to institutions devoted to restoration (Valladares and Gianoli, 2007).

In conclusion, an interdisciplinary approach involving scientists from different fields related to plants, soil, geomorphology, hydrology, ecological restoration and modelling should broaden our understanding of seed fate in overland flow and its ecogeomorphological consequences in vegetation structure and function to help fill the aforementioned gaps.

\section{The Supplement related to this article is available online at doi:10.5194/-15-131-2015-supplement.}

Acknowledgements. I am indebted to Artemi Cerdà and the executive editors of SOIL for their kind invitation to prepare this review. I am also grateful to Patricio García-Fayos for his suggestions, which helped improve the manuscript. I thank Topical Editor Richard Brazier, and Begoña Peco, Artemi Cerdà and two anonymous referees for providing helpful comments to improve the manuscript.

Edited by: R. E. Brazier

\section{References}

Aerts, R., Maes, W., November, E., Behailu, M., Poesen, J., Deckers, J., Hermy, M., and Muys, B.: Surface runoff and seed trapping efficiency of shrubs in a regenerating semiarid woodland in northern Ethiopia, Catena, 65, 61-70, 2006.

Aguiar, M. R. and Sala, O. E.: Seed distribution constrains the dynamics of the Patagonian steppe, Ecology, 78, 93-100, 1997.

Aguiar, M. R. and Sala, O. E.: Patch structure, dynamics and implications for the functioning of arid ecosystems, Trends Ecol. Evol., 14, 273-277, 1999.

Baskin, C. C. and Baskin, J. M. (Eds.): Seeds. Ecology, Biogeography, and Evolution of Dormancy and Germination, Academic Press, London, UK, 1998.

Bautista, S., Mayor, A., Bourakhouadar, J., and Bellot, J.: Plant spatial pattern predicts hillslope runoff and erosion in a semiarid mediterranean landscape, Ecosystems, 10, 987-998, 2007.

Bochet, E., Rubio, J. L., and Poesen, J.: Relative efficiency of representative matorral species in reducing water erosion at the microscale in a semi-arid climate, Geomorphology, 23, 139-150, 1998.

Bochet, E., Rubio, J. L., and Poesen, J.: Modified top soil islands within a patchy Mediterranean vegetation in SE Spain, Catena, 38, 23-44, 1999.

Bochet, E., Poesen, J., and Rubio, J. L.: Mound development as an interaction of individual plants with soil, water erosion and sedimentation processes on slopes, Earth Surf. Proc. Land., 25, 847-867, 2000. 
Bochet, E., Poesen, J., and Rubio, J. L.: Runoff and soil loss under individual plants of a semi-arid Mediterranean shrubland: influence of plant morphology and rainfall intensity, Earth Surf. Proc. Land., 31, 536-549, 2006.

Bochet, E., García-Fayos, P., and Poesen, J.: Topographic thresholds for plant colonization on semiarid eroded slopes, Earth Surf. Proc. Land., 34, 1758-1771, 2009.

Böhning-Gaese, K., Gaese, B. H., and Rabemanantsoa, S. B.: Importance of primary and secondary dispersal in the Malagasy tree Commiphora guillaumini, Ecology, 80, 821-832, 1999.

Boix-Fayos, C., Martínez-Mena, M., Calvo-Cases, A., Castillo, V., and Albaladejo, J.: Concise review of interrill erosion studies in SE Spain (Alicante and Murcia): erosion rates and progress of knowledge in the last two decades, Land Degrad. Dev., 16, 517 528, 2005

Boix-Fayos, C., Martínez-Mena, M., Arnau-Rosalén, E., CalvoCases, A., Castillo, V., and Albaladejo, J.: Measuring soil erosion by field plots: understanding the sources of variation, Earth-Sci. Rev., 78, 267-285, 2006.

Bullock, J. M., Shea, K., and Skarpaas, O.: Measuring plant dispersal: an introduction to field methods and experimental design, Plant Ecol., 186, 217-234, 2006.

Callaway, R. M. (Ed.): Positive Interactions and Interdependence in Plant Communities, Springer, Dordrecht, The Netherlands, 2007.

Calvo-Calves, A., Boix, C., and Imeson, A. C.: Runoff generation, sediment movement and soil water behaviour on calcareous (limestone) slopes of some mediterranean environments in southeast Spain, Geomorphology, 50, 269-291, 2003.

Cammeraat, L. H.: A review of two strongly contrasting geomorphological systems within the context of scale, Earth Surf. Proc. Land., 27, 1201-1222, 2002.

Cantón, Y., del Barrio, G., Solé-Benet, A., and Lázaro, R.: Topographic controls on the spatial distribution of ground cover in the Tabernas badlands of SE Spain, Catena, 55, 341-365, 2004.

Cerdà, A.: The effect of patchy distribution of Stipa tenacissima L. on runoff and erosion, J. Arid Environ., 36, 37-51, 1997.

Cerdà, A. and García-Fayos, P.: The influence of slope angle on sediment, water and seed losses on badland landscapes, Geomorphology, 18, 77-90, 1997

Cerdà, A. and García-Fayos, P.: The influence of seed size and shape on their removal by water erosion, Catena, 48, 293-301, 2002.

Chambers, J. C.: Seed movements and seedling fates in disturbed sagebrush steppe ecosystems: implications for restoration, Ecol. Appl., 10, 1400-1413, 2000.

Chambers, J. C. and MacMahon, J. A.: A day in the life of a seed: movements and fates of seeds and their implications for natural and managed systems, Annu. Rev. Ecol. Syst., 25, 263-292, 1994.

Chambers, J. C., MacMahon, J. A., and Haefner, J. H.: Seed entrapment in alpine ecosystems: effects of soil particle size and diaspore morphology, Ecology, 72, 1668-1677, 1991.

Deblauwe, V., Couteron, P., Bogaert, J., and Barbier, N.: Determinants and dynamics of banded vegetation pattern migration in arid climates, Ecol. Monogr., 82, 3-21, 2012.

Debusche, M. and Lepart, J.: Establishment of woody plants in mediterranean old-fields: opportunity in space and time, Landscape Ecol., 6, 133-145, 1992.

de Luís, M., Raventós, J., and González-Hidalgo, J. C.: Fire and torrential rainfall: Effects on seedling establishment in Mediter- ranean gorse shrublands, Int. J. Wildland Fire, 14, 413-422, 2005.

de Vente, J. and Poesen, J.: Predicting soil erosion and sediment yield at the basin scale: scale issues and semi-quantitative models, Earth-Sci. Rev., 71, 95-125, 2005.

Dunkerley, D. L. and Brown, K. J.: Runoff and runon areas in a patterned chenopod shrubland, arid western New South Wales, Australia: characteristics and origin, J. Arid Environ., 30, 41-55, 1995.

Ellner, S. and Shmida, A.: Why are adaptations for long-range seed dispersal rare in desert plants?, Oecologia, 51, 133-144, 1981.

Emmerson, L., Facelli, J. M., Chesson, P., and Possingham, H.: Secondary seed dispersal of Erodiophyllum elderi, a patchily distributed shortlived perennial in the arid lands of Australia, Austral. Ecol., 35, 906-918, 2010.

Emmerson, L. M., Facelli, J. M., Chesson, P., Possingham, H., and Day, J. R.: Changes in seed dispersal processes and the potential for between patch connectivity for an arid land daisy, Ecology, 93, 544-553, 2012.

Engelbrecht, M.: Mucilage secretion in seeds of Mediterranean species: hypotheses about its origin and function, $\mathrm{PhD}$ thesis, Universidad Complutense de Madrid, Facultad de Ciencias Biológicas, Departamento de Ecología, Spain, 199 pp., 2014.

Engelbrecht, M., Bochet, E., and García-Fayos, P.: Mucilage secretion: an adaptive mechanism to reduce seed removal by soil erosion?, Biol. J. Linn. Soc., 111, 241-251, 2014.

Espigares, T., Moreno-de las Heras, M., and Nicolau, J. M.: Performance of vegetation in reclaimed slopes affected by soil erosion, Restor. Ecol., 19, 35-44, 2011.

Fenner, M. (Ed.): Seed Ecology, Chapman and Hall, New York, USA, 151 pp., 1985.

Fernández, C., Vega, J. A., Jiménez, E, Vieira, D. C. S., Merino, A., Ferreiro, A., and Fonturbel, T.: Seeding and mulching + seeding effects on post-fire runoff, soil erosion and species diversity in Galicia (NW Spain), Land. Degr. Dev., 23, 150-156, 2012.

Forget, P. M. and Milleron, T.: Evidence for secondary seed dispersal in Panama, Oecologia, 87, 596-599, 1991.

Forget, P. M. and Wenny, D. G.: How to elucidate seed fate? A review of methods used to study seed removal and secondary seed dispersal, in: Seed Fate, Predation, Dispersal and Seedling Establishment, edited by: Forget, P., Lambert, J., Hulme, P., and Vander Wall, S., Cabi Publishing, UK, 379-393, 2002.

Francis, C. F.: Soil erosion and organic matter losses on fallow land: A case study from south-east Spain, in: Soil Erosion on Agricultural Land, edited by: Boardman, J., Foster, I. D. L., and Dearing, J. A., Wiley, Chichester, UK, 331-338, 1991.

Friedman, J. and Orshan, G.: The distribution, emergence and survival of seedlings of Artemisia herba-alba asso in the Negev Desert of Israel in relation to distance from the adult plants, J. Ecol., 63, 627-632, 1975.

Friedman, J. and Stein, Z.: The influence of seed-dispersal mechanisms on the dispersion of Anastatica hierochuntica (Cruciferae) in the Negev Desert, Israel, J. Ecol., 68, 43-50, 1980.

Gallart, F., Marignani, M., Pérez-Gallego, N., Santi, E., and Maccherini, S.: Thirty years of studies on badlands, from physical to vegetational approaches. A succinct review, Catena, 106, 4-11, 2013.

García-Fayos, P.: Interacciones entre la vegetación y la erosión hídrica, in: Ecología del bosque mediterráneo en un mundo cam- 
biante, edited by: Valladares, F., Ministerio de Medio Ambiente, EGRAF, S.A., Madrid, Spain, 309-334, 2004.

García-Fayos, P. and Bochet, E.: Indication of antagonistic interaction between climate change and erosion on plant species richness and soil properties in semiarid Mediterranean ecosystems, Global Change Biol., 15, 306-318, 2009.

García-Fayos, P. and Cerdá, A.: Seed losses by surface wash in degraded Meditterranean environments, Catena, 29, 73-83, 1997.

García-Fayos, P. and Recatalà, R. M.: La reserva de semillas en una cuenca de "badlands" (Petrer, Alicante), Pirineos, Revista de Ecología de Montaña, 140, 29-36, 1992.

García-Fayos, P., Cerdà, A., Recatalá, T. M., and Calvo, A.: Seed population dynamics on badland slopes in SE Spain, J. Veg. Sci., 6, 691-696, 1995.

García-Fayos, P., García-Ventoso, B., and Cerdá, A.: Limitations to plant establishment on eroded slopes in southeastern Spain, J. Veg. Sci., 11, 77-86, 2000.

García-Fayos P., Bochet, E., and Cerdà, A.: Seed removal susceptibility through soil erosion shapes vegetation composition, Plant Soil, 334, 289-297, 2010.

García-Fayos, P., Engelbrecht, M., and Bochet, E.: Postdispersal seed achorage to soil in semi-arid plant communities, a test of the hypothesis of Ellner and Shmida, Plant Ecol., 214, 941-952, 2013.

Govers, G.: A field study on topographical and topsoil effects on runoff generation, Catena, 18, 91-111, 1991.

Govers, G.: Grain velocities in overland flow: A laboratory experiment, Earth Surf. Proc. Land., 14, 481-489, 1989.

Guàrdia, R., Gallart, F., and Ninot, J. M.: Soil seed bank and seedling dynamics in badlands of the Upper Llobregat Basin (Pyrenees), Catena, 40, 189-202, 2000.

Guerrero-Campo, J. and Montserrat-Martí, G.: Effects of soil erosion on the floristic composition of plant communities on marl in northeast Spain, J. Veg. Sci., 11, 329-336, 2000.

Guerrero-Campo, J. and Montserrat-Martí, G.: Comparison of floristic changes on vegetation affected by different levels of soil erosion in Miocene clays and Eocene marls from Northeast Spain, Plant Ecol., 173, 83-93, 2004.

Han, L., Jiao, J., Jia, Y., Wang, N., Lei, D., and Li, L.: Seed removal on loess slopes in relation to runoff and sediment yield, Catena, 85, 12-21, 2011.

Harper, J. L. (Ed.): Population Biology of Plants, Academic Press, London, UK, 1977.

Howe, H. F. and Smallwood, J.: Ecology of seed dispersal, Annu. Rev. Ecol. Syst., 13, 201-228, 1982.

Hulme, P. E.: Post-dispersal seed predation: consequences for plant demography and evolution, Perspect. Plant Ecol., 1, 32-46, 1998.

Isselin-Nondedeu, F. and Bédécarrats, A.: Soil microtopographies shaped by plants and cattle facilitate seed bank formation on alpine ski trails, Ecol. Eng., 30, 278-285, 2007.

Isselin-Nondedeu, F., Rey, F., and Bédécarrats, A.: Contributions of vegetation cover and cattle hoof prints towards seed runoff control on ski pistes, Ecol. Eng., 27, 193-201, 2006.

Jiao, J., Zou, H., Jia, Y., and Wang, N.: Research progress on the effects of soil erosion on vegetation, Acta Ecol. Sin., 29, 85-91, 2009.

Jiao, J., Han, L., Jia, Y., Wang, N., Lei, D., and Li, L.: Can seed removal through soil erosion explain the scarcity of vegetation in the Chinese Loess Plateau?, Geomorphology, 132, 3-40, 2011.
Kéfi, S., van Baalen, M., Rietkerk, M., and Loreau, M.: Evolution of local facilitation in arid ecosystems, Am. Nat., 172, E1-E17, 2008.

Kirkby, M. J.: Modelling water erosion processes, in: Soil Erosion, edited by: Kirkby, M. J. and Morgan, R. P. C., Wiley, Chichester, UK, 183-216, 1980.

Ludwig, J. A. and Tongway, D. J.: Spatial-organization of landscapes and its function in semiarid woodlands, Australia, Landscape Ecol., 10, 51-63, 1995.

MacFadyen, W. A.: Soil and vegetation in British Somaliland, Nature, 165, p. 121, 1950.

Martínez-Casasnovas, J. A., Ramos, M. C., and Ribes-Dasi, M.: On site effects of concentrated flow erosion in vineyard fields: some economic implications, Catena, 60, 129-146, 2005.

Mauchamp, A., Montaña, C., Lepart, J., and Rambal, S.: Ecotone dependent recruitment of a desert shrub; Flourensia cernua, in vegetation stripes, Oikos, 68, 107-116, 1993.

Montaña, C., Seghieri, J., and Cornet, A.: Vegetation dynamics: recruitment and regeneration in two-phase mosaics, in: Banded vegetation patterning in arid and semiarid environments: ecological processes and consequences for management, edited by: Tongway, D. J., Valentin, C., and Seghieri, J., Springer, New York, USA, 20-31, 2001.

Moreno-de las Heras, M., Saco, P., Willgoose, G., and Tongway, D.: Assessing landscape structure and pattern fragmentation in semiarid ecosystems using patch-size distributions, Ecol. Appl., 21, 2793-2805, 2011.

Nearing, M. A., Pruski, F. F., and O’Neal, M. R.: Expected climate change impacts on soil erosion rates: a review, J. Soil Water Conserv., 59, 43-50, 2004.

Nelson, J. E. and Chew, R. M.: Factors affecting seed reserves in the soil of a Mojave desert ecosystem, Rock Valley, Nye County, Nevada, Am. Midl. Nat., 97, 300-320, 1977.

Parsons, A. J., Abrahams, A. D., and Luk, S.-K.: Size characteristics of sediment in interrill overland flow on a semiarid hillslope, southern California, Earth Surf. Proc. Land., 16, 143-152, 1991.

Parsons, A. J., Wainwright, J., and Abrahams, A. D.: Tracing sediment movement in interrill overland flow on a semi-arid grassland hillslope using magnetic susceptibility, Earth Surf. Proc. Land., 18, 721-732, 1993.

Parsons, A. J., Abrahams, A. D., and Wainwright, J.: Responses of interrill runoff and erosion rates to vegetation change in southern Arizona, Geomorphology, 14, 311-317, 1996.

Peart, M. H. and Clifford, H. T.: The influence of diaspore morphology and soil surface properties on the distribution of grasses, J. Ecol., 75, 569-576, 1987.

Peco, B., Ortega, M., and Levassor, C.: Similarity between seed bank and vegetation in Mediterranean grassland: a predictive model, J. Veg. Sci., 9, 815-828, 1998.

Poesen, J. and Savat, J.: Particle-size separation during erosion by splash and runoff, in: Assesment of Erosion, edited by: de Boodt, M. and Gabriels, D., Wiley, Chichester, UK, 427-439, 1980.

Porqueddu, C., Re, G. A., Sanna, F., Piluzza, G., Sulas, L., Franca, A., and Bullita, S.: Exploitation of annual and perennial herbaceous species for the rehabilitation of a sand quarry in a Mediterranean environment, Land Degrad. Dev., doi:10.1002/ldr.2235, online first, 2015. 
Pueyo, Y., Kéfi, S., Alados, C. L., and Rietkerk, M.: Dispersal strategies and spatial organization of vegetation in arid ecosystems, Oikos, 117, 1522-1532, 2008.

Puigdefábregas, J.: The role of vegetation patterns in structuring runoff and sediment fluxes in drylands, Earth Surf. Proc. Land., 30, 133-147, 2005.

Puigdefábregas, J. and Sánchez, G.: Geomorphological implications of vegetation patchiness on semi-arid slopes, in: Advances in Hillslope Processes, edited by: Anderson, M. G. and Brooks, S. M., Wiley, Chichester, UK, 1027-1060, 1996.

Puttock, A., Macleod, C. J. A., Bol, R., Sessford, P., Dungait, J., and Brazier, R. E.: Changes in ecosystem structure, function and hydrological connectivity control water, soil and carbon losses in semi-arid grass to woody vegetation transitions, Earth Surf. Proc. Land., 38, 1602-1611, 2013.

Reichman, O. J.: Spatial and temporal variation of seed distributions in Sonoran desert soils, J. Biogeogr., 11, 1-11, 1984.

Rey, F., Isselin-Nondedeu, F., and Bédécarrats, A.: Vegetation dynamics on sediment deposits upstream of bioengineering works in mountainous marly gullies in a Mediterranean climate (Southern Alps, France), Plant Soil, 278, 149-158, 2005.

Reynolds, J. F., Stafford Smith, D. M., Lambin, E. F., Turner, B. L., Mortimore, M., Batterbury, S. P. J., Downing, T. E., Dowlatabadi, H., Fernandez, R. b. J., Herrick, J. E., Huber-Sannwald, E., Jiang, H., Leemans, R., Lynam, T., Maestre, F. T., Ayarza, M., and Walker, B.: Global desertification: Building a science for dryland development, Science, 316, 847-851, 2007.

Rietkerk, M., Dekker, S. C., de Ruiter, P. C., and van de Koppel, J.: Self-organized patchiness and catastrophic shifts in ecosystems, Science, 305, 1926-1929, 2004.

Saco, P. M., Willgoose, G. R., and Hancock, G. R.: Ecogeomorphology of banded vegetation patterns in arid and semi-arid regions, Hydrol. Earth Syst. Sci., 11, 1717-1730, doi:10.5194/hess-11-1717-2007, 2007.

Schafer, D. E. and Chilcote, D. O.: Factors influencing persistence and depletion in buried seed populations. II. The effects of soil temperature and moisture, Crop Sci., 10, 342-345, 1970.

Schlesinger, W. H., Reynolds, J. F., Cunningham, G. L., Huenneke, L. F., Jarrell, W. M., Virginia, R. A., and Whitford, W. G.: Biological feedbacks in global desertification, Science, 247, 1043 1048, 1990.

Schupp, E. W.: Seed-seedling conflicts, habitat choice, and patterns of plant recruitment, Am. J. Bot., 82, 399-409, 1995.

Schurr, F. M., Bossdorf, O., Milton, S. J., and Schumacher, J.: Spatial pattern formation in semi-arid shrubland: a priori predicted versus observed pattern characteristics, Plant Ecol., 173, 271282, 2004

Seghieri, J., Galle, S., Rajot, J. L., and Ehrmann, M.: Relationships between soil moisture and growth of herbaceous plants in a natural vegetation mosaic in Niger, J. Arid Environ., 36, 87-102, 1997.

Siewert, W. and Tielborger, K.: Dispersal-dormancy relationships in annual plants: putting model predictions to the test, Am. Nat., 176, 490-500, 2010.

Specht, R. L. and Specht, A.: Global warming: predicted effects on structure and species richness of Mediterranean ecosystems in southern Australia, in: Time scales of Biological Responses to Water Constraints, eidited by: Roy, J., Aronson, J., and Di Cas- tri, F., SPB Academic Publishing, Amsterdam, The Netherlands, 215-237, 1995.

Thiéry, J., d'Herbès, J. M., and Valentin, C.: A model simulating the genesis of banding patterns in Niger, J. Ecol., 83, 497-507, 1995.

Thompson, K., Bond, S. R., and Hodgson, J. G.: Seed size and shape predict persistence in soil, Funct. Ecol., 7, 236-241, 1993.

Thompson, S. E., Assouline, S., Chen, L., Trahktenbrot, A., Svoray, T., and Katul, G.: Secondary dispersal driven by overland flow in drylands: Review and mechanistic model development, Movement Ecology, 2, 1-13, 2014.

Tongway, D. J. and Ludwig, J. A.: Theories on the origins, maintenance, dynamics and functioning of banded landscapes, in: Banded vegetation patterning in arid and semiarid environments: ecological processes and consequences for management, edited by: Tongway, D. J., Valentin, C., and Seghieri, J., Springer, New York, USA, 20-31, 2001.

Tormo, J., Bochet, E., and García-Fayos, P.: Roadslope revegetation in semiarid Mediterranean environments, Part II: topsoiling, species selection and hydroseeding, Restor. Ecol., 15, 97-102, 2007.

Traba, J., Azcárate, F. M., and Peco, B.: From what depth do seeds emerge? A soil seed bank experiment with Mediterranean grassland species, Seed Sci. Res., 14, 297-303, 2004.

Traba, J., Azcárate, F. M., and Peco, B.: The fate of seeds in Mediterranean soil seed banks in relation to their traits, J. Veg. Sci., 17, 5-10, 2006.

Tsuyuzaki, S. and Haruki, M.: Effects of microtopography and erosion on seedling colonisation and survival in the volcano Usu, northern Japan, after the 1977-78 eruptions, Land Degrad. Dev., 19, 233-241, 2008.

Turnbull, L., Wainwright, J., and Brazier, R. E.: A conceptual framework for understanding semi-arid land degradation: ecohydrological interactions across multiple-space and time scales, Ecohydrology, 1, 23-34, 2008.

Turnbull, L., Wainwright, J., and Brazier, R. E.: Biotic and abiotic changes in ecosystem structure over a shrub-encroachment gradient in the southwestern USA, Ecosystems, 13, 1239-1255, 2010.

Turnbull, L., Wilcox, B. P., Belnap, J., Ravi, S., D’Odorico, P., Childers, D., Gwenzi, W., Okin, G., Wainwright, J., Caylor, K. K., and Sankey, T.: Understanding the role of ecohydrological feedbacks in ecosystem state change in drylands, Ecohydrology, 5, 174-183, 2011.

Valentin, C., d'Herbès, J. M., and Poesen, J.: Soil and water components of banded vegetation patterns, Catena, 37, 1-24, 1999.

Valladares, F. and Gianoli, E.: How much ecology do we need to know to restore Mediterranean ecosystems?, Restor. Ecol., 15, 363-368, 2007.

Vander Wall, S., Forget, P., Lambert, J., and Hulme, P.: Seed fate pathways: filling the gap between parent and offspring, in: Seed Fate, Predation, Dispersal and Seedling Establishment, edited by: Forget, P., Lambert, J., Hulme, P., and Vander Wall, S., Cabi Publishing, UK, 1-8, 2002.

Venable, L., Flores-Martínez, A., Muller-Landau, H. C., BarronGafford, G., and Becerra, J. X.: Seed dispersal of desert annuals, Ecology, 89, 2218-2227, 2008.

Wainwright, J.: Infiltration, runoff and erosion characteristics of agricultural land in extreme storm event, SE France, Catena, 26, 27-47, 1996. 
Wainwright, J., Parsons, A. J., and Abrahams, A. D.: Plot-scale studies of vegetation, overland flow and erosion interactions: case studies from Arizona and New Mexico, Hydrol. Proc., 14, 2921-2943, 2000.

Wang, D., Jiao, J., Lei, D., Wang, N., Du, H., and Jia, Y.: Effects of seed morphology on seed removal and plant distribution in the Chinese hill-gully Loess Plateau region, Catena, 104, 144-152, 2013.
Wang, N., Jiao, J.-Y., Lei, D., Chen, Y., and Wang, D. L.: Effect of rainfall erosion: seedling damage and establishment problems, Land Degrad. Dev., 25, 565-572, doi:10.1002/ldr.2183, 2014.

Wilcox, B. P., Breshears, D. D., and Allen, C. D.: Ecohydrology of a resource-conserving semiarid woodland: Effects of scale and disturbance, Ecol. Monogr., 73, 223-239, 2003.

Winkelmolen, A. M.: Rollability, a functional shape property of sand grains, J. Sediment. Petrol., 41, 703-714, 1971. 